\title{
Borrelia burgdorferi Elicited-IL-10 Suppresses the Production of Inflammatory Mediators, Phagocytosis, and Expression of Co-Stimulatory Receptors by Murine Macrophages and/or Dendritic Cells
}

\author{
Yutein Chung ${ }^{\circledR}$, Nan Zhang ${ }^{\circledR}$, R. Mark Wooten* \\ Department of Medical Microbiology and Immunology, University of Toledo College of Medicine, Toledo, Ohio, United States of America
}

\begin{abstract}
Borrelia burgdorferi $(\mathrm{Bb})$ is a tick-borne spirochete that is the causative agent for Lyme disease. Our previous studies indicate that virulent $\mathrm{Bb}$ can potently enhance IL-10 production by macrophages (MØs) and that blocking IL-10 production significantly enhances bacterial clearance. We hypothesize that skin-associated APC types, such as MØs and dendritic cells (DCs) are potent producers of IL-10 in response to Bb, which may act in autocrine fashion to suppress APC responses critical for efficient Bb clearance. Our goal is to delineate which APC immune functions are dysregulated by Bb-elicited IL-10 using a murine model of Lyme disease. Our in vitro studies indicated that both APCs rapidly produce IL-10 upon exposure to $\mathrm{Bb}$, that these levels inversely correlate with the production of many Lyme-relevant proinflammatory cytokines and chemokines, and that APCs derived from IL-10 ${ }^{-/-}$mice produced greater amounts of these proinflammatory mediators than wild-type APCs. Phagocytosis assays determined that Bbelicited IL-10 levels can diminish Bb uptake and trafficking by MØs, suppresses ROS production, but does not affect NO production; Bb-elicited IL-10 had little effect on phagocytosis, ROS, and NO production by DCs. In general, Bb exposure caused little-to-no upregulation of several critical surface co-stimulatory markers by M $\varnothing \mathbf{s}$ and DCs, however eliminating Bb-elicited IL-10 allowed a significant upregulation in many of these co-stimulatory receptors. These data indicate that IL-10 elicited from Bb-stimulated $\mathrm{M} \varnothing \mathrm{s}$ and $\mathrm{DCs}$ results in decreased production of proinflammatory mediators and co-stimulatory molecules, and suppress phagocytosis-associated events that are important for mediating both innate and adaptive immune responses by APCs.
\end{abstract}

Citation: Chung Y, Zhang N, Wooten RM (2013) Borrelia burgdorferi Elicited-IL-10 Suppresses the Production of Inflammatory Mediators, Phagocytosis, and Expression of Co-Stimulatory Receptors by Murine Macrophages and/or Dendritic Cells. PLoS ONE 8(12): e84980. doi:10.1371/journal.pone.0084980 Editor: Brian Stevenson, University of Kentucky College of Medicine, United States of America

Received November 4, 2013; Accepted November 27, 2013; Published December 19, 2013

Copyright: @ 2013 Chung et al. This is an open-access article distributed under the terms of the Creative Commons Attribution License, which permits unrestricted use, distribution, and reproduction in any medium, provided the original author and source are credited.

Funding: The funding for this study was $\mathrm{NIH}$ grant R01 Al073452. The funders had no role in study design, data collection and analysis, decision to publish, or preparation of the manuscript.

Competing interests: The authors have declared that no competing interests exist.

*E-mail: r.mark.wooten@utoledo.edu

- These authors contributed equally to this work.

a Current address: Departments of Pediatrics and Communicable Diseases, University of Michigan Medical School, Ann Arbor, Michigan, United States of America

\section{Introduction}

Lyme disease is caused by the tick-borne spirochetal bacterium Borrelia burgdorferi (Bb)[1]. After deposition into the skin of susceptible hosts, this pathogen can rapidly migrate through skin tissues to infect and persist within many different tissues [2]. If diagnosed and treated with appropriate antibiotics in a timely manner, these bacteria are usually cleared from most patients without lasting symptoms. However, in the absence of antibiotic treatment, these pathogens can persist for months to years in a wide range of host tissues. Persistent bacteria can periodically "re-emerge" in those tissues to elicit inflammatory responses that cause the widely varying sequellae associated with Lyme disease; this is most commonly observed as inflammation in large joints, nervous and neurologic abnormalities, and cardiac-associated disorders. Notably, immunocompetent hosts are able to produce potent innate and adaptive immune responses against $\mathrm{Bb}$ during the course of infection. In vitro studies have shown that macrophages and neutrophils can phagocytose and kill $\mathrm{Bb}$ quite efficiently, particularly if Bb-specific antibodies are present [3-5]. While the adaptive immune response to $\mathrm{Bb}$ is somewhat delayed, the antibodies produced during this response are able to bind $\mathrm{Bb}$ and mediate killing in vitro and passive transfer of these antisera into naïve mice are able to prevent subsequent infection by similar $\mathrm{Bb}$ strains $[6,7]$. 
However, even though $\mathrm{Bb}$ appears to disseminate and persist largely within the extracellular tissues, where they should be readily accessible to both cellular and soluble immune mediators, these innate and adaptive immune effectors are unable to effectively clear these pathogens. Thus there is great interest in identifying the mechanisms that allow $\mathrm{Bb}$ to evade these immune responses.

Appropriate innate immune responses appear to be particularly critical in controlling the development of Lyme disease [1,8]. The $\mathrm{Bb}$ genome encodes $\geq 127$ different lipoproteins (e.g. $\sim 8 \%$ of all open reading frames), many of which are believed to be important for their ability to rapidly adapt and persist within tick and vertebrate hosts [2,9-13]. While these numerous lipoproteins likely provide different biological functions, all appear to possess similar triacyl modifications at the amino terminal that promote their trafficking and insertion into the $\mathrm{Bb}$ outer membrane $[14,15]$. Murine studies have shown that innate receptors, most notably CD14 and toll-like receptor 2 (TLR2), can recognize the common triacyl motif on these lipoproteins and initiate inflammatory responses via MyD88-dependent pathways [16-20]. These TLR2-mediated signaling pathways are critical for macrophage $(M \varnothing)$ activation by $B b$ lipoproteins, leading to more efficient intracellular trafficking of $\mathrm{Bb}$, and the production of a wide range of inflammatory mediators believed important for promoting $\mathrm{Bb}$ clearance [21,22]. It is likely that these pathways are also used in a number of other immune and nonimmune cell types that are also directly activated by $\mathrm{Bb}$ lipoproteins, including dendritic cells (DCs) $[23,24]$, neutrophils [25], mast cells [26], B cells [27], and endothelial cells [28,29]. Importantly, TLR2-deficient (TLR2 ${ }^{-1-}$ ) mice infected with $\mathrm{Bb}$ possess up to 100 -fold higher bacterial loads than wild-type mice in different tissues at both early and late times postinfection, even though these TLR2 $2^{-/-}$mice produced Bb-specific antibodies at similar levels and of similar Bb-antigen specificity as infected wild-type mice [21,30]. These findings highlight the ability of these spirochetes to efficiently evade the adaptive immune responses and the importance of innate responses in controlling $\mathrm{Bb}$ levels during all stages of infection.

The anti-inflammatory cytokine $\mathrm{IL}-10$ is known to play a significant role in the development of Lyme disease [31]. IL-10 can be produced by a number of different leukocyte and nonimmune cell types in response to various stimuli, but the most potent production is usually associated with myeloid cells and certain $T$ cell subsets $[32,33]$. The timely elicitation of IL-10 in tissues is critical for the dampening and resolution of inflammatory responses, as extended immune activation would result in inadvertent damage to host tissues. Patients with deficiencies in IL-10 often develop disease manifestations related to uncontrolled inflammatory conditions, such as inflammatory bowel disorder, rheumatoid arthritis, and several autoimmune diseases [34], thus confirming the important and central role this cytokine plays in modulating inflammatory signaling. A number of in vitro studies have reported that monocytes/macrophages exposed to intact $\mathrm{Bb}$ or a standard $\mathrm{Bb}$ recombinant lipoprotein (OspA) exhibit a potent IL-10 response [35-37]. Primary $\mathrm{M} \varnothing \mathrm{s}$ derived from mouse lines known to develop either severe $(\mathrm{C} 3 \mathrm{H} / \mathrm{HeN} ; \mathrm{C} 3 \mathrm{H})$ or mild
(C57BL/6; B6) Lyme disease during $\mathrm{Bb}$ infection showed that $\mathrm{B} 6 \mathrm{M} \varnothing$ s display a significantly greater IL-10 response to OspA lipoprotein than $\mathrm{C} 3 \mathrm{H} \mathrm{MØs,} \mathrm{and} \mathrm{that} \mathrm{addition} \mathrm{of} \mathrm{physiologic}$ levels of IL-10 to OspA-stimulated $\mathrm{C} 3 \mathrm{H}$ MØs reduced their production of proinflammatory cytokines to levels observed in B6 $\mathrm{M} \varnothing \mathrm{s}$, suggesting these differences in IL-10 production might influence the severity of Lyme disease [37,38]. Infection studies using B6 mice lacking a functional IL-10 gene (IL-10 $0^{-/-}$) showed these animals developed increased ankle swelling and arthritis severity compared to wild-type controls, even though the IL-10 ${ }^{-/}$mice maintained $\sim 10$-fold less bacteria in affected tissues [37]. Gene microarray analyses of infected joint tissues from $\mathrm{B} 6-\mathrm{IL}-10^{-/-}$mice determined that the gene expression patterns were more similar to those for infected $\mathrm{C} 3 \mathrm{H}$ mice displaying severe disease, as opposed to infected B6 mice that develop mild disease [39], and blocking these IL-10 mediated responses reduced the infiltration of different immune cells whose presence is associated with increased arthritis severity [40], suggesting an important role for IL-10 in mediating Lymeassociated pathology. Notably, infected IL-10 $1-$ mice possess significantly reduced levels of $\mathrm{Bb}$ loads in ankle and other tissues compared to B6 mice [37]. Although infected IL-10\%mice do possess higher Bb-specific antibody levels than B6 mice, this enhanced ability to clear $\mathrm{Bb}$ infection appears to occur largely via effects on the innate immune response [41]. This IL-10 response is rapid, as substantial production is seen by macrophages in vitro within 4-6h after co-culture and significant increases in IL-10 transcript levels are seen in skin tissues within $24 \mathrm{~h}$ post-infection with a physiological dose of $\mathrm{Bb}$ $[41,42]$. The IL-10 ${ }^{-/-}$mouse is currently the only infection model where manipulation of a single soluble immune mediator can significantly enhance $\mathrm{Bb}$ clearance in multiple target tissues, thus there is great interest in better understanding the mechanisms affected during $\mathrm{IL}-10$ suppression of $\mathrm{Bb}$ clearance.

$M \varnothing s$ and DCs are believed to be important for initiating the immune response to $\mathrm{Bb}$ infection, due to their proximity in the skin, ability to phagocytose and be activated by $\mathrm{Bb}$, ability to initiate inflammatory responses, and ability to act as antigenpresenting cells (APCs) in initiating adaptive immunity [43,44]. Both of these APCs are known to be major producers of IL-10 in response to different stimuli, and are also known to downregulate several of their immune mechanisms in response to IL-10 [33]. Based on the ability of $\mathrm{Bb}$ to elicit strong IL-10 production, we hypothesize that $\mathrm{M} \varnothing \mathrm{s}$ and DCs are major producers of IL-10 in response to $\mathrm{Bb}$, which can then act in an autocrine fashion to suppress immune activities that are critical for the control of $\mathrm{Bb}$ infection. The goal of these studies is to determine the relative abilities of $M \varnothing s$ and $D C s$ to produce $\mathrm{IL}-10$ in response to $\mathrm{Bb}$, and delineate whether these IL-10 levels affect their abilities to suppress immune mechanisms that are critical for mediating both innate and adaptive immune responses to $\mathrm{Bb}$. 


\section{Materials and Methods}

\section{$B$. burgdorferi growth and viability}

A clonal $\mathrm{N} 40$ isolate of $\mathrm{Bb}$ [45] was provided by Steve Barthold (University of California, Davis), and were maintained in BSK-II medium [46] supplemented with 6\% rabbit serum (Pel-Freez Biologicals)(BSK-II). A B31-5A-14 Bb isolate engineered to express eGFP from the borrelial erpAB promoter [47] was provided by Brian Stevenson (University of Kentucky, Lexington) and was maintained in BSK-II containing $200 \mu \mathrm{g} / \mathrm{ml}$ kanamycin. For all experiments, both strains were grown at $33^{\circ} \mathrm{C}$ for $3-5$ days before enumerating by direct counting using a Petroff-Hauser chamber and dark field microscopy. All in vitro experiments were performed using bacteria that are between passages 4-7 ex vivo.

\section{Animal usage}

C57BL/6 (B6) wild-type mice were purchased from Charles River Laboratories (NCl-Frederick). B6.129P2-IL-10tm1Cgn/J mice lacking a functional IL-10 gene (IL-10-/) were purchased from The Jackson Laboratory. All animals were housed in the Department of Lab Animal Research at the University of Toledo Health Science Campus according to National Institute of Health guidelines for the care and use of laboratory animals. All usage protocols were reviewed and approved by the Institutional Animal Care and Usage Committee (IACUC) at the University of Toledo.

1. Expansion of primary $M \varnothing$ and $D C$ for in vitro analyses. Bone marrow-derived primary $M \varnothing s$ were prepared as previously described [41]. Briefly, dissociated marrow tissues from the limb bones of $\mathrm{B} 6$ or IL-10-/ mice were isolated and cultured for 6 days in RPMI media containing 30\% L929 cell supernatants and $10 \%$ FBS. Adherent cells were collected, enumerated, and re-seeded onto tissue culture plates as indicated for the particular assay. Bone marrow-derived primary DCs were prepared as previously described [48]. Briefly, dissociated marrow tissues were cultured for 5 days in RPMI media containing 10ng/ml recombinant GM-CSF (R\&D Systems) and $10 \%$ FBS, then the non-adherent cells were collected, enumerated, and seeded onto tissue culture plates as indicated for the particular assay in medium lacking GMCSF. Before using in experiments, the phenotype of these expanded $M \varnothing$ and DC populations was examined by flow cytometry (FACSCalibur ${ }^{\mathrm{TM}}$, BD Biosciences) using fluorescent antibodies (BD Biosciences-Pharmingen) against murine CD11b, CD11c, F4/80, and MHC class II (Figure 1). In general, naïve $M \varnothing$ s were high in $C D 11 b$ and $F 4 / 80$, while low on $M H C$ class II and CD11c, whereas naïve DCs were high in CD11b, CD11C and MHC class II (Figure 1).

\section{In vitro ELISA analyses}

Naïve MØs and DCs were seeded on 24-well tissue-culture treated plates at $4 \times 10^{5}$ cells per well in $0.5 \mathrm{ml}$ of RPMl containing $10 \%$ FBS and $20 \%$ BSK-II medium (RPMI-B) and allowed to adhere overnight. $\mathrm{Bb}$ were added at a multiplicity of infection (MOI) of 10 , centrifuged at $300 \times \mathrm{g}$ for $5 \mathrm{~min}$ to facilitate contact, and incubated at $37^{\circ} \mathrm{C}$ in $5 \% \mathrm{CO}_{2}$. For some
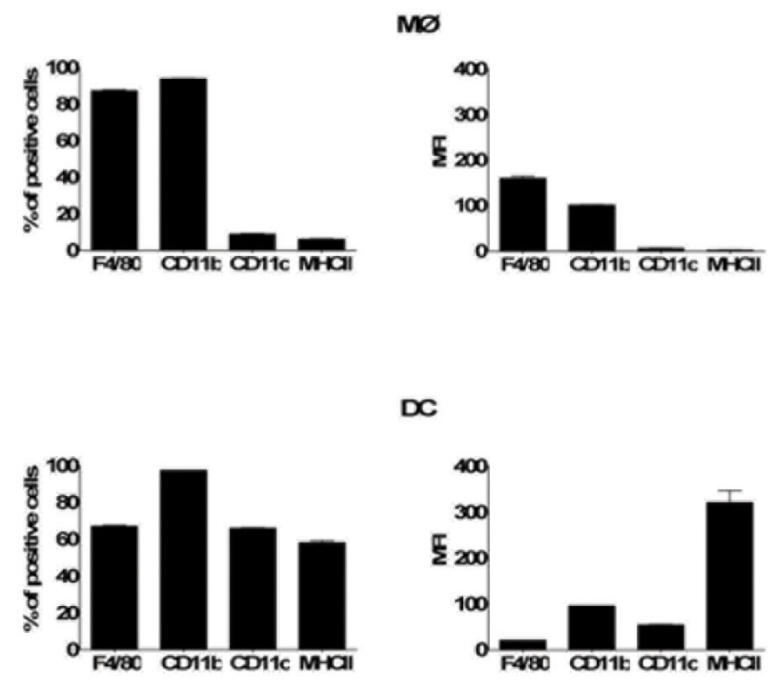

DC

Figure 1. Surface markers on naïve MØs and DCs. Bone marrow-derived naïve $\mathrm{M} \varnothing \mathrm{s}$ and $\mathrm{DCs}$ were collected prior to addition of $\mathrm{Bb}$, stained with antibodies specific for the indicated surface markers, and analyzed by flow cytometry.

doi: 10.1371/journal.pone.0084980.g001

experiments, co-culture was performed in the presence of an IL-10-blocking antibody $(3 \mu \mathrm{g} / \mathrm{ml}$; BD Biosciences), thus allowing delineation of effects due to IL-10 versus those inherent to the IL-10-deficient background of the IL-10-/- APCs. At the indicated times post-infection, supernatants were collected and either frozen for later use or immediately assessed for cytokine content by sandwich ELISA using our previously described methods [37,41]. ELISA plates were prepared using paired mAbs and cytokine standards (BD Biosciences), and bound cytokines were visualized using avidin-HRP (Vector Laboratories) and quantified at 490nm using a Versamax ${ }^{\circledR}$ (Molecular Devices) 96-well plate reader. All experimental conditions were performed in triplicate and repeated in at least 4 separate experiments.

\section{Quantitative RT-PCR}

Naïve $M \varnothing$ s and DCs were seeded on 12-well tissue-culture treated plates at $1 \times 10^{6}$ cells per well in $1 \mathrm{ml}$ of RPMI-B and allowed to adhere overnight. $\mathrm{Bb}$ were added at a $\mathrm{MOI}=10$, centrifuged at $300 \times \mathrm{g}$ for $5 \mathrm{~min}$ to facilitate contact, and incubated at $37^{\circ} \mathrm{C}$ in $5 \% \mathrm{CO}_{2}$. At the indicated times postinfection, total RNA was harvested from each triplicate well using an RNeasy ${ }^{\circledR}$ kit (Qiagen). Total RNA was reverse transcribed into cDNA using ImProm $I \circledast$ reverse transcriptase (Promega) per the manufacturer's instructions. cDNA was quantified by real-time quantitative PCR (Q-PCR) using a Light Cycler (Roche) rapid fluorescence temperature cycler, as previously described [41]. The PCR primer sets were purchased through Integrated DNA Technologies and are listed in Table 1. Data are plotted as fold change over $\beta$-actin, where the values for the unstimulated wild-type control over $\beta$-actin were set $=1$, and all other values were normalized to their own 
$\beta$-actin values and compared to the wild-type control. Similar experiments were performed at least three times.

\section{Immunofluorescence microscopy and phagocytosis assay}

Naïve MØs and DCs were seeded in 12-well plates containing glass cover slips at $2 \times 10^{5}$ cells per well in RPMI.B. For DCs, glass cover slips were coated with $0.01 \%$ poly-Llysine (Sigma) for at least 24 hours prior to cell seeding to enhance cell adherence. Seeded APCs were either left untreated or were pre-treated overnight with live Bb N40 (MOI = 10) or recombinant IL-10 (2ng/ml; BD Pharmingen) before performing the assay. For the phagocytosis assay, green fluorescent protein (GFP)-producing Bb B31 were added to each well at a $\mathrm{MOI}=10$ and centrifuged at $300 \times \mathrm{g}$ for $3 \mathrm{~min}$ to facilitate Bb-APC contact. At the indicated times post-infection, supernatants were removed and the cells washed $2 x$ in PBS to remove unbound $\mathrm{Bb}$. $\mathrm{APCs}$ were then fixed in $4 \%$ paraformaldehyde overnight prior to immunochemical staining. To identify lysosomal compartments, fixed APCs were membrane-permeablized with $1 \%$ Triton-X-100 and stained with $2 \mu \mathrm{g} / \mathrm{ml}$ of a Lysosomal-associated membrane protein 1 (LAMP)-1-specific antibody (ID4B; Developemental Hybridoma, University of lowa) and visualized with $2 \mu \mathrm{g} / \mathrm{ml}$ tetramethylrhodamineisothiocyanate (TRITC)-goat anti-rat antibody (Southern Biotech). 4',6-diamidino-2-phenylindole (DAPI; Fisher Scientific) was added at $250 \mathrm{nM}$ to visualize the nuclei. Cover slips containing the stained APCs were mounted onto glass slides using Fluoromount ${ }^{\circledR}$ (Southern Biotech) and examined by phase and immunofluorescence microscope (Leica DM IRB inverted microscope). Epifluorescent images of fields containing $75-150$ APCs were captured at 200x magnification and overlayed on bright-field images using $Q$ Capture ${ }^{\circledR}$ software (QImaging software); at least three separate fields were assessed for each slide. For quantitative analysis of phagocytosis, the percentage of APCs containing at least one internalized $\mathrm{Bb}$ particle was determined for each field (\#APCs containing Bb/total number of APCs). This ratio was averaged for the total fields per triplicate slides in three independent experiments.

\section{Determination of reactive oxygen intermediates (ROI)}

Naïve MØs and DCs were seeded in 96-well black plates with clear bottom (Costar) at $10^{5}$ cells per well in RPMI.B for 10 to $15 \mathrm{~h}$ prior to $\mathrm{Bb}$-stimulation. Immediately preceding stimulation, the RPMI.B media was washed to remove serum

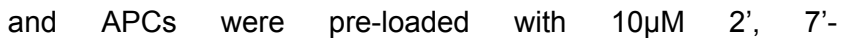
dichlorodihydrofluorescein-diacetate (DCFH-DA, i.e. DCF; Invitrogen) in serum-free HBSS for 15 minutes at $37^{\circ} \mathrm{C}$ before washing to remove the excess dye. These loaded APCs were incubated for an additional $30 \mathrm{~min}$ in fresh HBSS at $37^{\circ} \mathrm{C}$ in the absence or presence of the indicated agonists/antagonists prior to stimulation with $\mathrm{Bb}$. $\mathrm{Bb}$ were then added at $\mathrm{MOI}=10$, centrifuged at $300 \times \mathrm{g}$ for $3 \mathrm{~min}$ to facilitate Bb-APC contact, and immediately assessed for fluorescence using a FLUOstar Omega microplate reader (BMG LABTECH). Some samples received the NADPH oxidase inhibitor DPI $(10 \mu \mathrm{M})$ to block the ROS response; $10 \mu \mathrm{M}$ was shown in preliminary experiments to
Table 1. List of PCR primers used.

\begin{tabular}{|c|c|c|}
\hline Primer & Forward (5' 3') & Reverse (5' 3') \\
\hline CXCL1 (KC) & $\begin{array}{l}\text { GGG ATT CAC CTC AAG } \\
\text { AAC ATC CAG }\end{array}$ & $\begin{array}{l}\text { TTT CTG AAC CAA GGG AGC } \\
\text { TTC AGG }\end{array}$ \\
\hline CCL3 (MIP-1a) & $\begin{array}{l}\text { CCG GAA TTC CGG AGA } \\
\text { CTC TCA GGC ATT CAG TT }\end{array}$ & $\begin{array}{l}\text { CGC GGA TCC GCG ATG } \\
\text { AAG GTC TCC ACC ACT GC }\end{array}$ \\
\hline CCL4 (MIP-1ß) & $\begin{array}{l}\text { CGC GGA TCC GCG ATG } \\
\text { AAG CTC TGC GTG TCT } \\
\text { GC }\end{array}$ & $\begin{array}{l}\text { CCG GAA TTC CGG GCT } \\
\text { GGA GCT GCT CAG TTC AA }\end{array}$ \\
\hline $\begin{array}{l}\text { CXCL2 } \\
(\mathrm{MIP}-2 \alpha)\end{array}$ & $\begin{array}{l}\text { AGT GAA CTG CGC TGT } \\
\text { CAA TG }\end{array}$ & $\begin{array}{l}\text { GAG AGT GGC TAT GAC TTC } \\
\text { TGT CTG }\end{array}$ \\
\hline CCL2 (MCP-1) & $\begin{array}{l}\text { AGC AGG TGT CCC AAA } \\
\text { GAA GCT GTA }\end{array}$ & $\begin{array}{l}\text { AAA GGT GCT GAA GAC CTT } \\
\text { AGG GCA }\end{array}$ \\
\hline $\begin{array}{l}\text { CCL5 } \\
\text { (RANTES) }\end{array}$ & $\begin{array}{l}\text { GCC CAC GTC AAG GAG } \\
\text { TAT TTC TAC }\end{array}$ & $\begin{array}{l}\text { CTT GAA CCC АCT TCT TCT } \\
\text { CTG G }\end{array}$ \\
\hline$\beta$-actin & $\begin{array}{l}\text { TGG AAT CCT GTG GCA } \\
\text { TCC ATG AAA C }\end{array}$ & $\begin{array}{l}\text { TAA AAC GCA GCT CAG TAA } \\
\text { CAG TCC G }\end{array}$ \\
\hline
\end{tabular}

doi: 10.1371/journal.pone.0084980.t001

completely suppress ROS responses without being toxic to cells, as assessed by trypan blue exclusion and MTT assay (data not shown). The relative fluorescent intensity units (RFU) and the change in RFU over time were acquired at $480 \mathrm{~nm}$ excitation/520nm emission at $1 \mathrm{~min}$ intervals for $45 \mathrm{~min}$.

\section{Determination of reactive nitrogen intermediates (RNI)}

Naïve MØs and DCs were seeded on 24-well tissue-culture treated plates at $4 \times 10^{5}$ cells per well in $0.5 \mathrm{ml}$ of RPMI.B and allowed to adhere overnight. $\mathrm{Bb}$ were added at a $\mathrm{MOI}=10$, centrifuged at $300 \times \mathrm{g}$ for $5 \mathrm{~min}$ to facilitate contact, and incubated at $37^{\circ} \mathrm{C}$ in $5 \% \mathrm{CO}_{2}$. At the indicated times postinfection, supernatants were collected and assessed for nitric oxide (NO) production using the Griess assay to determine nitrite $\left(\mathrm{NO}_{2}\right)$ levels as described previously [49]. Briefly, equal volumes of $1 \%$ sulfanilamide in $30 \%$ acetic acid and $0.1 \% \mathrm{~N}-(1-$ napthyl) ethylenediamine dihydrochloride in $60 \%$ acetic acid were added to $50 \mu \mathrm{l}$ of cell supernatants in a 96-well plate. $\mathrm{NO}_{2}$ levels were determined based on the absorbance values acquired at $570 \mathrm{~nm}$ wavelengths and compared to a $\mathrm{NaNO}_{2}$ standard using a Versamax® plate reader (Molecular Devices).

\section{Detection of APC surface molecules}

Naïve MØs and DCs were seeded onto 6-well plates at $3 \mathrm{x}$ $10^{6}$ cells/well in $1 \mathrm{ml} \mathrm{RPMI.B}$ and allowed to adhere overnight. $\mathrm{Bb}$ were added at $\mathrm{MOI}=10$, centrifuged at $300 \times \mathrm{g}$ for $5 \mathrm{~min}$ to facilitate contact, and incubated at $37^{\circ} \mathrm{C}$ in $5 \% \mathrm{CO}_{2}$. At the indicated times post-infection, the recovered cells were transferred to polystyrene tubes and incubated for $30 \mathrm{~min}$ with blocking buffer (PBS containing 1\% BSA) along with $10 \mu \mathrm{g} / \mathrm{ml}$ anti-Fc receptor antibodies (BD Pharmingen) on ice. APCs were then incubated with either FITC- or PE-conjugated mAbs against cell surface markers CD11b, CD11c, MHC II, CD80, CD86, CD40, F4/80, or appropriate isotype controls (BD Pharmingen) at $5 \mu \mathrm{g} / \mathrm{ml}$ for $20 \mathrm{~min}$ on ice. APCs were then washed $3 x$ with cold PBS, and fluorescent levels measured 
using a FACS Caliber ${ }^{\circledR}$ flow cytometer (BD Biosciences). Quantitative analysis of the flow cytometry data (e.g. mean fluorescent intensity and percent positive) was performed using Cellquest (BD Biosciences) and FlowJo (Tree Star, Inc.) software.

\section{Statistical analyses}

Statistical analyses were performed using InStat software (GraphPad Software). Based on these software determinations, the quantitative differences between sample groups were determined by either Kruskal-Wallis (nonparametric ANOVA) followed by Dunn's Multiple Comparisons Test, parametric ANOVA followed by a Tukey Test, or twotailed Student's T test. $P$ values of $<0.05$ were considered to be significant.

\section{Results}

\section{Bb elicit high levels of IL-10 production by both $M \varnothing s$ and DCs that suppress cytokine responses}

Kinetic studies were performed to assess the production of IL-10 by M $\varnothing$ s and DCs, as well as its effect on production of pro-inflammatory cytokines. The addition of $\mathrm{Bb}$ to $\mathrm{B} 6 \mathrm{M} \varnothing \mathrm{s}$ and DCs elicited significant levels of secreted IL-10 within $8 \mathrm{~h}$ of simulation, as determined by ELISA (Figure 2). Intact Bb also elicited a variety of pro-inflammatory cytokines by both $M \varnothing s$ and DCs with similar kinetics to IL-10, albeit at relatively low levels; these include IL-6, IL-12, and TNFa. To test whether the Bb-elicited IL-10 suppresses the production of proinflammatory cytokines from both APC types, parallel experiments were performed with $M \varnothing s$ and $D C s$ isolated from IL-10 ${ }^{-/}$mice. As expected, IL-10 $0^{-/}$APCs do not produce IL-10 in response to $\mathrm{Bb}$, however, the production of all assessed proinflammatory cytokines were significantly higher than that produced by B6 APCs (Figure 2).

To confirm whether these findings were directly due to $\mathrm{Bb}$ elicted IL-10 rather than effects inherent to IL-10-deficiency, parallel experiments were performed using B6 APCs stimulated with $\mathrm{Bb}$ in the presence of neutralizing antibodies against IL-10 ( $\alpha$ IL-10). These antibodies were able to neutralize all the IL-10 produced in vitro by the APCs (Figure 3), and this blockage resulted in a similar increase in the production of proinflammatory cytokines after $\mathrm{Bb}$ co-culture as seen in the $\mathrm{IL}-10^{-1-}$ APCs (compare Figures 2 and 3). Together, these findings indicate that both $\mathrm{M} \varnothing \mathrm{s}$ and $\mathrm{DCs}$ are major producers of $\mathrm{Bb}$-elicited IL-10, and that these levels of IL-10 can act back on $\mathrm{M} \varnothing \mathrm{s}$ and DCs to suppress the production of proinflammatory cytokines involved in inflammatory responses to $\mathrm{Bb}$.

\section{Chemokine production by MØs and DCs is suppressed by Bb-elicited IL-10}

Neutrophil-recruiting chemokines such as CXCL1 (i.e. KC) are known to play critical roles during $\mathrm{Bb}$ infection $[50,51]$. Since MØs and DCs are major producers of chemokines, we assessed whether Bb-elicited IL-10 can down-regulate chemokine production by APCs. The chemokines assessed
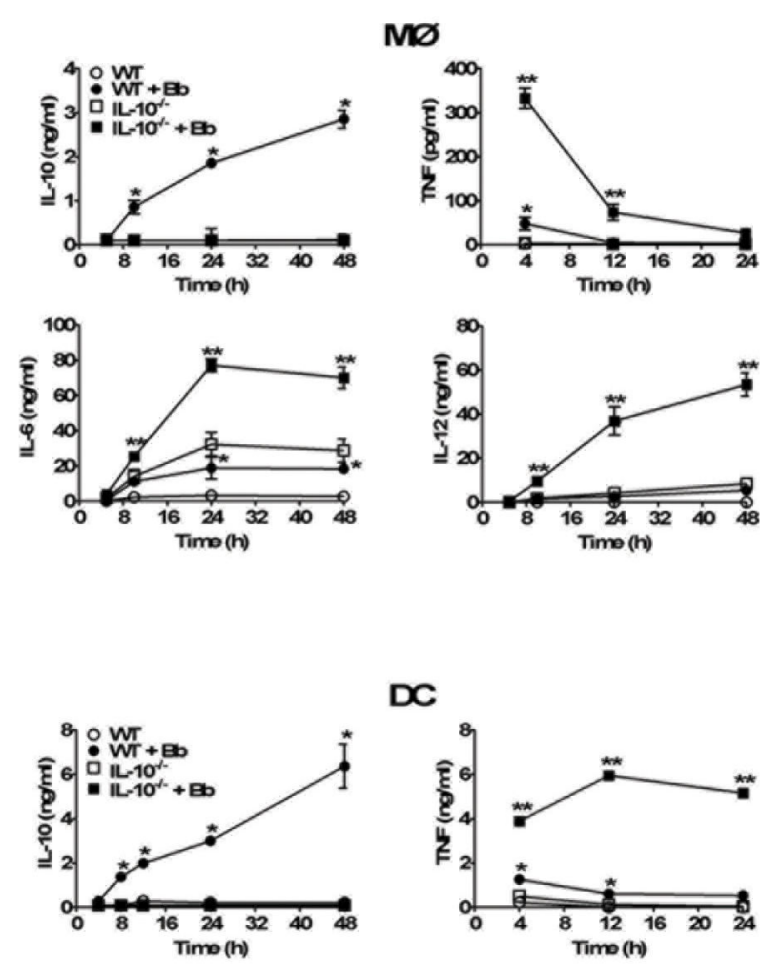

DC
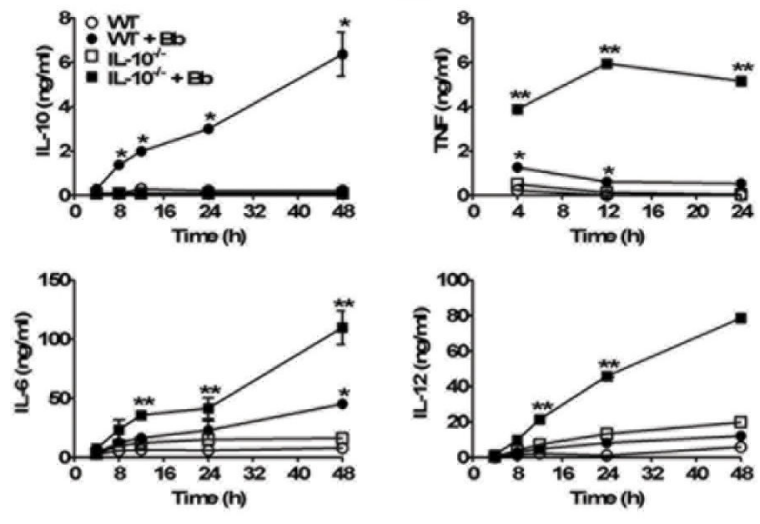

Figure 2. Effects of Bb-elicited IL-10 on the production of proinflammatory cytokines by $M \varnothing s$ and $D C s$ in vitro. $M \varnothing s$ (upper panel) or DCs (lower panel) derived from either wild type (wt) $\mathrm{C} 57 \mathrm{BL} / 6$ or IL-10\% mice were co-cultured with $\mathrm{Bb}$ $(\mathrm{MOI}=10)$ at $37 \mathrm{C}^{\circ}$. Culture supernatants were collected at the indicated times post-stimulation and cytokine content assessed by ELISA. Each symbol represents the average of triplicate samples from at least three separate experiments. Statistically significant $(P<0.05)$ values are indicated between $B b-$ stimulated versus unstimulated APCs $\left({ }^{*}\right)$, or stimulated B6 versus IL-10-/- APCs $\left(^{* *}\right)$.

doi: 10.1371/journal.pone.0084980.g002

were chosen to sample those capable of attracting a range of leukocytes; CXCL1 (KC) and CXCL2 (GROß) attract neutrophils, whereas CCL2 (MCP-1), CCL3 (MIP-1a), CCL4 (MIP-1 $\beta$ ), and CCL5 (RANTES) are more directed towards monocyte/macrophages and $\mathrm{T}$ cells. Addition of $\mathrm{Bb}$ induced upregulation of transcript levels for all chemokines assessed, including CXCL1, CXCL2, CCL2, CCL3, CCL4, and CCL5 by $\mathrm{M} \varnothing \mathrm{s}$ and DCs as early as $4 \mathrm{~h}$ post-infection (Figure 4). These transcript levels continued to increase over $12 \mathrm{~h}$ poststimulation in DCs, whereas transcript levels in MØs appeared 

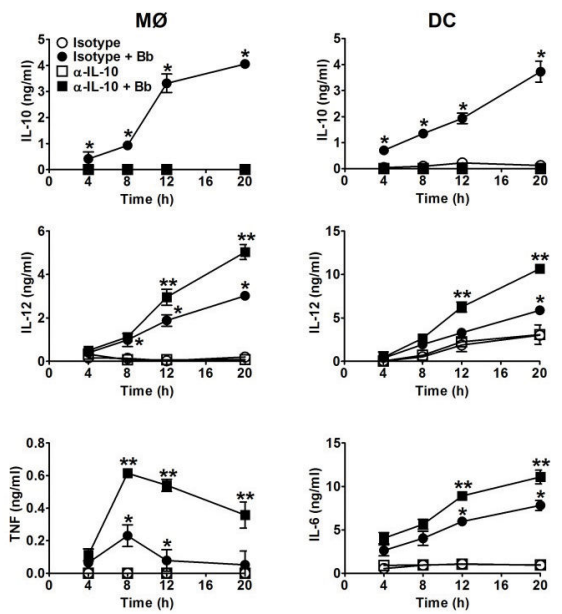

Figure 3. Use of IL-10-blocking antibodies to assess IL-10 effects on MØs and DC cytokines. Experiments were performed as in Figure 2, except $M \varnothing s$ and $D C$ from B6 mice were preincubated with $3 \mu \mathrm{g} / \mathrm{ml}$ of either an IL-10-blocking (alL-10) or isotype control antibody for 30 min before adding $\mathrm{Bb}$ $(\mathrm{MOI}=10)$ at $37^{\circ} \mathrm{C}$. Each symbol represents the average of triplicate samples from at least three separate experiments. Statistically significant $(P<0.05)$ values are indicated between Bb-stimulated versus unstimulated APCs $\left({ }^{*}\right)$, or stimulated isotype Ab-treated B6 versus alL-10-treated APCs $\left({ }^{* *}\right)$. doi: 10.1371/journal.pone.0084980.g003

relatively consistent over this timeframe. Addition of $\mathrm{Bb}$ to IL-10 $\%$ APCs displayed a significantly enhanced upregulation of many chemokines at $4 \mathrm{~h}$ compared to B6 APC, including CXCL1, CXCL2, and CCL3, as well as CCL2 in DCs only. By $12 \mathrm{~h}$ post-infection, all chemokines assessed in both $\mathrm{IL}-10^{-/-}$ APC types were upregulated compared to B6 cells, indicating that $\mathrm{Bb}$-elicited IL-10 does suppress chemokine production by both MØs and DCs.

\section{IL-10 inhibits $\mathrm{Bb}$ uptake and trafficking by $\mathrm{M} \varnothing \mathrm{s}$}

To assess whether Bb-elicited IL-10 directly affects phagocytosis of $\mathrm{Bb}$ by APCs, MØs and DCs were seeded onto glass coverslips, co-incubated with a GFP-expressing B31 strain of $\mathrm{Bb}$, and images were captured at different times postinfection by immunofluorescence microscopy (IM). Bb intake by MØs occurred as early as 5 min post-infection, as demonstrated by the presence of tightly circularized $\mathrm{Bb}$ particles (green) within the APCs (Figure 5A, top panels), and these numbers were slightly increased at 15 and 30 min postinfection. Co-staining with LAMP-1-specific antibodies indicated that $\mathrm{Bb}$ were trafficked to LAMP-1-containing compartments within $15 \mathrm{~min}$, and most internalized $\mathrm{Bb}$ showed co-localization in lysosomal compartments by $30 \mathrm{~min}$. DCs showed a similar kinetics of $\mathrm{Bb}$ uptake and trafficking as $\mathrm{M} \varnothing \mathrm{s}$, though the total numbers appears to be less (Figure 5A, lower panels). Pretreatment of $\mathrm{M} \varnothing \mathrm{s}$ and DCs with cytochalasin $\mathrm{D}$ completely inhibited the internalization, as all $\mathrm{Bb}$ were observed in
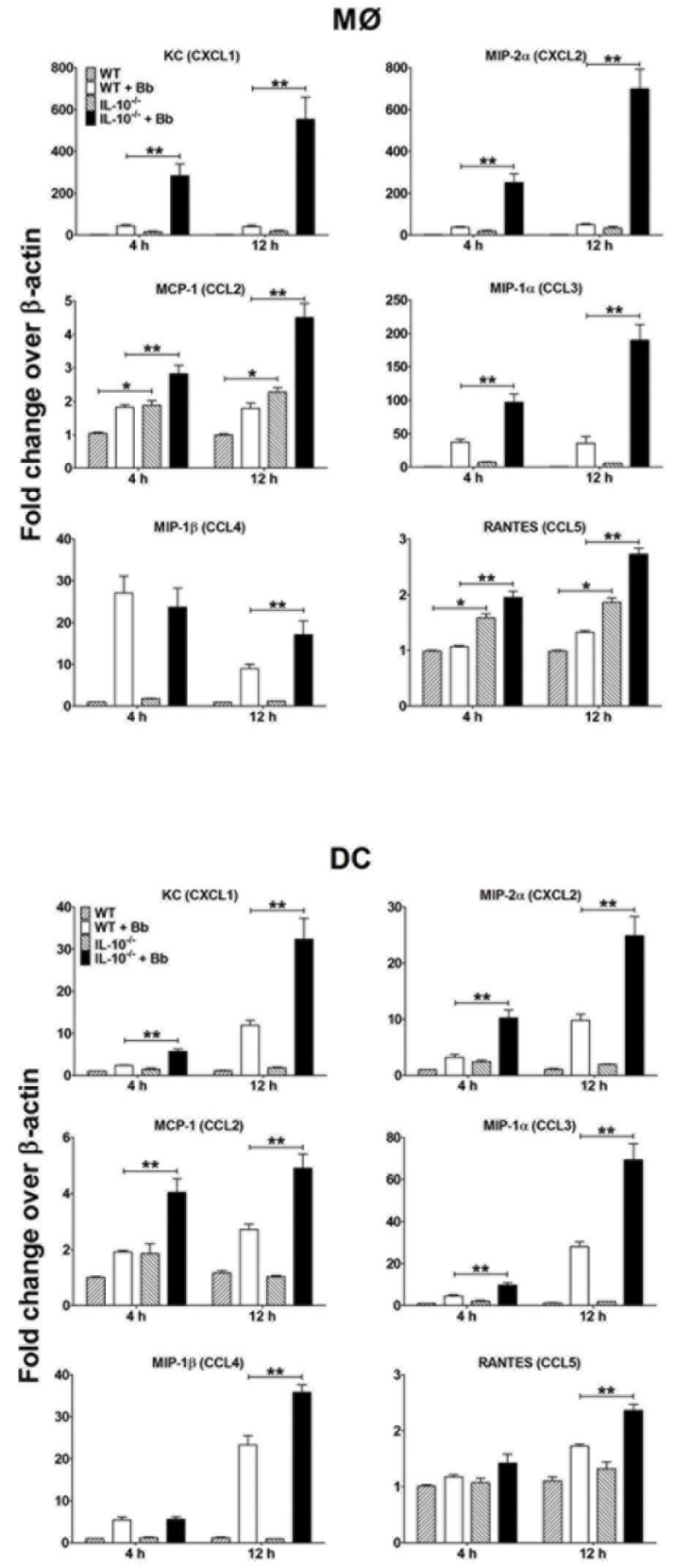

Figure 4. Effects of Bb-elicited IL-10 on chemokine expression by APCs: MØs (upper panel) and DCs (lower panel) from $\mathrm{B} 6$ and IL-10 ${ }^{-/-}$mice co-cultured with $\mathrm{Bb}$ at $\mathrm{MOI}=10$ at $37^{\circ} \mathrm{C}$. APCs were collected at the indicated times post-stimulation and total RNA was purified and reverse transcribed into cDNA for Q-PCR analyses. The transcript levels of each chemokine are normalized to levels of $\beta$-actin for each sample and reported as fold-induced over the baseline values for unstimulated MØs (upper panel) and DCs (lower panel). Each bar represents the average of triplicate samples from at least three separate experiments. Statistically significant values are indicated between unstimulated and $\mathrm{Bb}-$ stimulated APCs $\left({ }^{*}\right)$, or stimulated B6 versus IL-10 ${ }^{-1-}$ APCs $\left({ }^{* *}\right)$. doi: 10.1371/journal.pone.0084980.g004 
spirochetal form outside of APCs at all times post-infection (data not shown).

To quantify whether IL-10 affects the uptake and trafficking of $\mathrm{Bb}$ by APCs, the percentages of cells containing internalized, "non-linear" Bb particles were compared between B6 APCs and those pretreated with a physiological level of rIL-10 (based on levels observed in Bb-stimulated APCs; Figure 2). At 30 min post-infection, $M \varnothing$ s pre-treated with rIL-10 demonstrated a significant reduction in percent $\mathrm{Bb}$ intake as compared to control MØs (Figure 5B). As another physiological model, IL-10 was induced naturally by pre-treating $M \varnothing s$ with non-fluorescent $\mathrm{N} 40 \mathrm{Bb}$ overnight before re-infecting the same MØs with the fluorescent GFP-B31 strain. This treatment produced a similar reduction in $\mathrm{Bb}$ intake as those treated with exogenous rIL-10. To delineate whether the suppression for the "re-infection group" is due to IL-10, neutralizing IL-10 antibody was added during the pretreatment with $\mathrm{N} 40 \mathrm{Bb}$, which resulted in the uptake reverting back to the control MØs levels; pre-treatment with an isotype control antibody had not such effect. Parallel assays were performed to determine the effects of $\mathrm{IL}-10$ on $\mathrm{Bb}$ phagocytosis by DCs (Figure $5 \mathrm{~B}$ ). Control DCs displayed a slightly lower rate of $\mathrm{Bb}$ uptake as observed by $\mathrm{M} \varnothing \mathrm{s}$, however the addition of rlL-10 or pretreatment with $\mathrm{Bb}$ did not appear to significantly affect $\mathrm{Bb}$ uptake and trafficking by DCs. These data suggest that Bbelicited IL-10 suppresses phagocytosis of Bb by MØs, but not DCs.

\section{Bb-elicited IL-10 suppresses the production of reactive oxygen intermediates (ROI) and reactive nitrogen intermediates (RNI) by $\mathrm{M} \varnothing \mathrm{s}$ in response to $\mathrm{Bb}$}

Live $\mathrm{Bb}$ and $\mathrm{Bb}$ components are capable of eliciting ROls in phagocytic cells $[25,52,53]$. To test whether Bb-elicited ROI production in MØs and DCs is affected by IL-10, a DCF-based assay was employed to detect intracellular ROI levels in response to $\mathrm{Bb}$. Co-culture of $\mathrm{Bb}$ with $\mathrm{M} \varnothing$ s caused a significant upregulation of ROI, as indicated by both the raw RFU units as well as the slope of change (Figure 6A). Pretreatment of MØs with a physiological amount of $\mathrm{rL}-10\left(1 \mathrm{ng} / 10^{5}\right.$ cells) before adding $\mathrm{Bb}$ caused a significant reduction in $\mathrm{ROI}$ compared to $\mathrm{Bb}$ treatment alone, and this suppressed response was similar to that seen in untreated MØs or cells treated with rIL-10 alone. $\mathrm{M} \varnothing \mathrm{s}$ stimulated with $\mathrm{Bb}$ in the presence of the NADPH oxidase inhibitor, diphenylene iodonium (DPI), showed no increase in RFU values, indicating the ROS was internally generated. Parallel experiments using DCs indicated these cells were unable to elicit significant $\mathrm{ROI}$ in response to $\mathrm{Bb}$. These data indicate that $\mathrm{Bb}$-elicited IL-10 can inhibit ROI production by $\mathrm{M} \varnothing$ s exposed to $\mathrm{Bb}$.

The effects of IL-10 on RNI production by MØs and DCs in response to viable $\mathrm{Bb}$ was assessed using the Griess assay. The addition of $\mathrm{Bb}$ to $\mathrm{M} \varnothing \mathrm{s}$ caused a significant upregulation of nitric oxide at $24 \mathrm{~h}$ post-stimulation (Figure 6B). While MØs from $\mathrm{IL}-10^{-/-}$mice had higher inherent nitric oxide production compared to $\mathrm{B} 6 \mathrm{M} \varnothing \mathrm{s}$, addition of $\mathrm{Bb}$ to IL-10-1- MØs did display a significant increase compared to Bb-stimulated $\mathrm{B} 6 \mathrm{M} \varnothing \mathrm{s}$ at both 12 and $24 \mathrm{~h}$ post-stimulation. Parallel experiments using $\mathrm{DCs}$ showed that $\mathrm{Bb}$ co-culture produced a significant
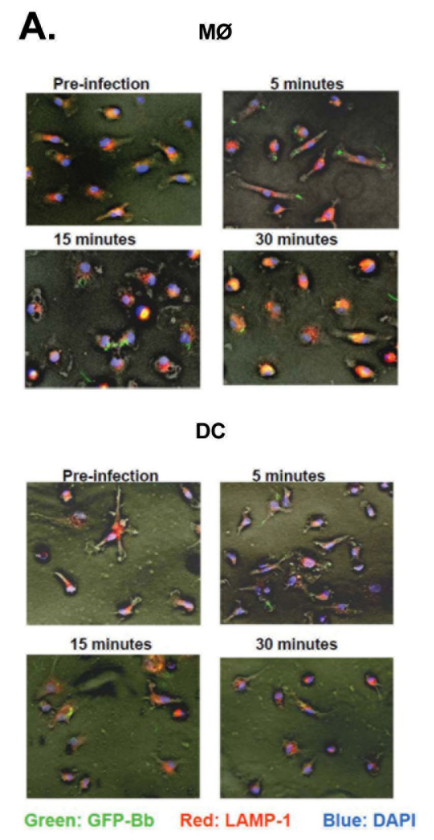

B.

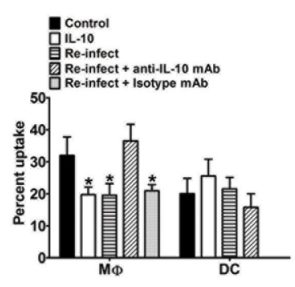

Figure 5. Effect of IL-10 on Bb uptake and trafficking by APCs. A. MØs (upper panel) and DCs (lower panel) from B6 mice were cultured on glass coverslips and infected with GFPexpressing (green) $\mathrm{Bb}(\mathrm{MOI}=10)$ at $37^{\circ} \mathrm{C}$. At 5,15 , and $30 \mathrm{~min}$ post-infection, APCs were fixed with $4 \%$ paraformaldehyde and permeablized for staining of LAMP-1 using TRITC-labeled (red) antibodies; nuclei are stained with DAPI (blue). Immunofluorescent images (200x) are representative of triplicate samples from three separate experiments, each with at least 3 different fields of views. (B) Quantitative analysis of $\mathrm{Bb}$ phagocytosis by APCs. MØs and DCs from B6 mice were infected with GFP-expressing $\mathrm{Bb}$ as in $\mathrm{A}$ (above) under five different conditions: GFP-Bb only (control), recombinant IL-10 $(2 \mathrm{ng} / \mathrm{ml})$ administered overnight prior to GFP-Bb infection (rlL-10), infected with non-fluorescent $\mathrm{Bb}$ overnight prior to GFP-Bb infection (Re-infect), same as Re-infect, but initial infection was performed in the presence of anti-IL-10 antibody (Re-infect + anti-IL-10 mAb) or an isotype control (Re-infect + isotype $\mathrm{mAb}$ ). Percent internalization was calculated as percentage of APCs per field of view containing internalized $\mathrm{Bb}$ at $30 \mathrm{~min}$ post-Bb infection. Data represents the average of ten separate fields of views, each containing 75-150 APCs, comprising at least three separate experiments. * Indicates statistically significant values $(P \leq 0.05)$ compared to cells cultured with GFP-Bb only.

doi: 10.1371/journal.pone.0084980.g005 

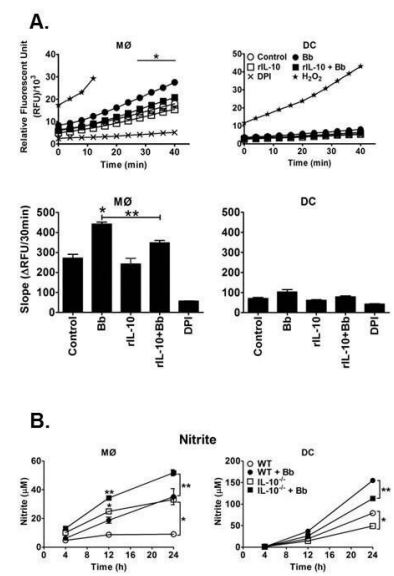

Figure 6. Effects of IL-10 on Bb-induced ROS and RNI production by APCs. A. MØs (left panels) and DCs (right panels) were cultured in 96-well plates for $15 \mathrm{~h}$ before loading with DCF for $15 \mathrm{~min}$. Cells were then pre-treated with or without rIL-10 (2ng/10 cells) or the NADPH oxidase inhibitor $\mathrm{DPI}(10 \mu \mathrm{M})$ for an additional $30 \mathrm{~min}$ prior to Bb-stimulation; $0.01 \% \mathrm{H}_{2} \mathrm{O}_{2}$ provided a positive control. ROS production was assessed by detecting the relative fluorescence intensity (RFU) values for up to $40 \mathrm{~min}$ post-stimulation. Top: Data are expressed as raw RFU values per min over a 40 min interval (Left: MØs, Right: DCs). Middle: Slope of RFU for each condition is calculated as changes in RFU over time for the first $30 \mathrm{~min}$. Data are representative of three separate experiments. Statistically significant $(P<0.05)$ values are indicated compared to unstimulated control $\left(^{*}\right)$ or $\mathrm{Bb}$ stimulation $\left(^{* *}\right)$. B. MØs (left panels) and DCs (right panels) were stimulated with $\mathrm{Bb}$ for $24 \mathrm{~h}$. Supernatant nitric oxide (nitrite) levels were assessed using the Griess assay. Statistically significant $(P<0.05)$ values are indicated compared to unstimulated controls $\left(^{*}\right)$ or $\mathrm{Bb}$ stimulation $\left({ }^{* *}\right)$.

doi: 10.1371/journal.pone.0084980.g006

upregulation of $\mathrm{NO}$ at $24 \mathrm{~h}$ post-stimulation compared to control DCs (Figure 6B), similar to the trend observed with MØs. Conversely, IL-10-/- DCs displayed lower nitric oxide production compared to $\mathrm{B} 6$ both in the presence and absence of $\mathrm{Bb}$. These data indicate that Bb-elicited IL-10 can suppress RNI responses by $\mathrm{M} \varnothing \mathrm{s}$, but not $\mathrm{DCs}$, in response to $\mathrm{Bb}$ stimulation.

\section{$\mathrm{Bb}$ in the presence/absence of IL-10 has varied effects on regulating co-stimulatory molecules on the surface of APCs}

Another important function of MØs and DCs are to serve as APCs to drive $T$ cell activation in response to pathogens. Because expression of certain co-stimulatory surface receptors are central to APC activation of $T$ cells, the effects of $B b$ stimulation and Bb-elicited IL-10 on expression of a subset of these receptors was assessed by flow cytometry. All MØs appears to express CD40 and Bb stimulation did not change the density of this receptor in the presence or absence of IL-10 (Figure 7A). The percentage of MØs expressing CD80, CD86, and $\mathrm{MHC}$ class II did not change after co-culture with $\mathrm{Bb}$,
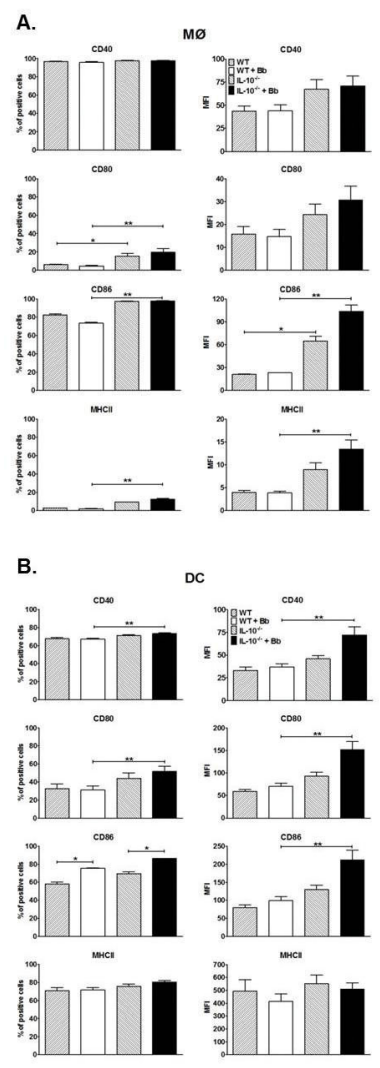

Figure 7. Effect of IL-10 on Bb-elicited upregulation of surface co-stimulation molecule expression on APCs. MØs (A) and DCs (B) expanded from B6 and IL-10-1mice were cultured with $\mathrm{Bb}$ for $24 \mathrm{~h}$ before staining with fluorescence antibodies specific for the indicated surface molecules and analyzed by flow cytometry. Data are reported both as percentage of positive cells (left panels) and mean fluorescent intensity (MFI). Each bar represents triplicate samples from at least three separate experiments. Statistically significant $(\mathrm{P}<0.05)$ values are indicated compared to unstimulated $\left({ }^{*}\right)$ or Bb-stimulated APCs $\left({ }^{* *}\right)$.

doi: 10.1371/journal.pone.0084980.g007

though the absence of $\mathrm{IL}-10$ appeared to increase the percentage of cells expressing CD80 independent of $\mathrm{Bb}$ stimulation. Assessment of $\mathrm{IL}-10^{-/-} \mathrm{M} \varnothing \mathrm{s}$ indicated that $\mathrm{Bb}-$ elicited IL-10 had no effect on the density of CD80 expression after $\mathrm{Bb}$ activation, however it did downregulate the density of CD86 and MHC II, though the absence of IL-10 did appear to upregulate CD86 levels irrespective of $\mathrm{Bb}$ stimulation. Overall, these findings suggest that $\mathrm{M} \varnothing \mathbf{s}$ do not upregulate any of the assessed co-stimulatory surface receptors in response to $\mathrm{Bb}$, and some of these reduced responses appear due to the presence of Bb-elicited IL-10.

Assessment of DCs indicated that $\mathrm{Bb}$ co-culture increased the percentage of cells expressing CD86, but had no effect on the percentage of cells expressing the other assessed surface receptors (Figure 7B). Bb stimulation alone also had no effect on the density of all of the assessed co-stimulatory receptors 
on DCs. Assessment of IL-10 $1 /$ DCs indicated that Bb-elicited IL-10 can suppress the percentage of cells expressing CD40 and CD80, but had little effect on the percentage of cells expressing CD86 and MHC II compared to Bb stimulation alone. Bb-elicited IL-10 did significantly suppress the density of CD40, CD80, and CD86 expressed on Bb-stimulated DCs, but had no effect on MHC II density. Overall, these findings suggest that DCs only upregulate CD86 among all of the costimulatory receptors assessed in response to $\mathrm{Bb}$ stimulation, and many of these reduced responses appears due to the presence of Bb-elicited IL-10.

\section{Discussion}

$\mathrm{Bb}$ is an obligate parasite whose natural infection cycle requires it to persist in an immunocompetent host for an extended time post-infection. This pathogen largely resides within the extracellular matrix of multiple tissues and appropriate innate responses appear critical for controlling infection. MØs and neutrophils appear able to phagocytose and clear $\mathrm{Bb}$ in vitro, however the $\mathrm{ID}_{50}$ is $\mathbf{5 0}$ organisms in vivo, suggesting their responses are much less efficient within host tissues. Previous work in our lab and others $[35,36]$ indicates that $\mathrm{Bb}$ causes a rapid and substantial increase in $\mathrm{IL}-10$ production by $\mathrm{M} \varnothing \mathrm{s}$, and that $\mathrm{IL}-10$ adversely affects $\mathrm{Bb}$ clearance in vivo mainly via inhibition of innate immune responses $[37,41]$. Based on these findings, we speculate that certain skin resident APC's are the major producer of Bbelicited IL-10, which then act to suppress critical immune properties of these resident cells that are necessary to initiate and modulate an effective immune response. Our goal was to assess the relative abilities of $M \varnothing s$ and DCs to elicit IL-10 in response to $\mathrm{Bb}$, and to delineate any detrimental effects this $\mathrm{IL}-10$ has on their ability to phagocytose/traffic $\mathrm{Bb}$, as well as to subsequently produce inflammatory mediators and express surface co-stimulation markers that are associated with effective clearance of pathogenic bacteria.

In this study, bone marrow-derived $\mathrm{M} \varnothing \mathrm{s}$ and DCs displayed rapid IL-10 production in response to $\mathrm{Bb}$, with levels apparent between 4-8 post-infection, and which continued to increase throughout the $48 \mathrm{~h}$ period they were assessed. The kinetics of IL-10 production was similar between MØs and DCs, though DCs appeared to produce $\sim 2$-fold higher levels at all times assessed. These kinetics were similar to those previously reported by our group and others for $\mathrm{M} \varnothing \mathrm{s}$ in vitro [41,42,54,55], and correlate with the rapid IL-10 increase seen in the skin of infected mice [42]. Studies by Sonderegger et al have reported that $\mathrm{M} \varnothing \mathrm{s}$ and $\mathrm{CD4}^{+} \mathrm{T}$ cells are the major producers of $\mathrm{Bb}$ elicited IL-10 in infected mouse joints, though these levels were assessed at $\geq 2$ weeks post-infection [40]. However, it is unlikely that $\mathrm{CD}^{+} \mathrm{T}$ cells would be involved in the increased IL-10 levels seen in infected skin 24-48h post-infection by previously naïve mice, particularly with the well-documented delay in adaptive immune response to $\mathrm{Bb}$ infection, as there would be insufficient time for the development of Bb-specific $\mathrm{T}$ cells [7]. Based on our described kinetics of IL-10 production and their presence as skin-resident cells, it is likely that $M \varnothing s$ and DCs are a significant source of Bb-elicited IL-10 at these early times post-infection.

To address whether the IL-10 elicited by these skin-resident APCs might influence the ability of adjacent cells to recognize and kill $\mathrm{Bb}$, assays were performed to assess phagocytosis characteristics and production of mediators associated with bacterial killing. In these studies, Bb were taken up by $\mathrm{M} \varnothing \mathrm{s}$ and DCs as early as 5 min post-infection, packaged relatively tightly into phagosomal compartments, and localized to the vicinity of LAMP-1 containing compartments as early as $15-30$ min after intake, which was similar to other published studies assessing phagocyte clearance of $\mathrm{Bb}$ [22,56-58]. The effects of Bb-elicited IL-10 on phagocytosis was tested in two ways: 1) pretreatment with physiologic doses of rlL-10 (based on Figure 2) and 2) pretreatment with non-fluorescent $\mathrm{Bb}$ to elicit natural production of IL-10. In each of these cases, the trafficking of $\mathrm{Bb}$ to LAMP-1-containing compartments by $\mathrm{M} \varnothing$ s was significantly suppressed by 30 min post-infection, and the suppression was lost in the presence of IL-10-blocking antibodies, confirming that the effects were IL-10-specific. Thus, Bb-elicited IL-10 appears to have a direct effect on phagocytosis and trafficking of $\mathrm{Bb}$ by $\mathrm{M} \varnothing \mathrm{s}$, and presumably affects the killing efficiency during clearance. Alternatively, uptake and clearance by BMDCs appeared to be relatively unaffected by IL-10. This could be a reflection of the somewhat lower phagocytosis rate exhibited by DCs compared to MØs, but more likely reflects a general mechanistic difference between MØs and DCs in terms of $\mathrm{Bb}$ retention and killing (see discussion below).

The production of various ROls and RNIs, such as superoxide $\left(\mathrm{O}_{2}^{-}\right)$, hydrogen peroxide $\left(\mathrm{H}_{2} \mathrm{O}_{2}\right)$, hydroxyl radicals $(\mathrm{OH})$, and nitric oxide (NO), during activation of phagocytes are essential to the killing of many bacterial pathogens [59-61]. There have been reports that IL-10 can affect the generation of $\mathrm{ROI}$ and RNI in response to certain pathogens [62-64], but little is known regarding $\mathrm{Bb}$. In the current studies, $\mathrm{Bb}$ elicited significant production of $\mathrm{ROI}$ and $\mathrm{RNI}$ from $\mathrm{M} \varnothing \mathrm{s}$, similar to results previously reported by our lab and others $[21,65,66]$, and also elicited RNI from DCs, which is previously unreported for $\mathrm{Bb}$. However, introduction of physiological levels of IL-10 significantly reduced the production of both $\mathrm{ROI}$ and $\mathrm{NO}$ by MØs. Alternatively, while DCs showed increased production of $\mathrm{NO}$, but not $\mathrm{ROI}$, in response to $\mathrm{Bb}$, these IL-10 levels were unable to suppress the relatively low levels produced by DCs. Whereas MØs are well-known for their ability to phagocytose and kill pathogens, largely through RNI, ROS, and other phagosomal mediators, "classical" dendritic cells are more known for their ability to phagocytose pathogens and subsequently present antigens to $T$ cells $[61,67,68]$. It is possible that the differences seen on IL-10 effects between $\mathrm{M} \varnothing \mathrm{s}$ and DCs may reflect the generally lessened production of $\mathrm{RNI}$ and ROS by DCs compared to MØs. More directed studies to determine if these effects are common to all of the different DCs subsets that have recently been identified are beyond the scope of this study $[69,70]$. The importance of ROI and NO in controlling Lyme disease is unclear. Infection of mice that lack functional NADPH oxidase or iNOS determined they possess similar $\mathrm{Bb}$ levels and arthritis development as control mice $[65,71,72]$. However, ROI and RNI can damage various $\mathrm{Bb}$ 
components, such as lipoproteins $[63,64]$ and proteins containing free or zinc-containing cysteine thiols [73]. Bb does express SOD, which is required for Bb survival in the host [74]. Notably, $\mathrm{Bb}$ also lacks both free iron and iron-containing enzymes, suggesting they may be less susceptible to ROSmediated damage [75]. Thus, while $\mathrm{Bb}$ appears well-adapted to evade damage via ROS and RNI-mediated mechanisms, the suppressive effects conferred by Bb-elicited IL-10 would add to this resistance.

Activation of MØs and other skin-resident immune cells by pathogens usually leads to production of proinflammatory mediators that act to recruit particular immune cells from the vasculature and activate them in the vicinity of these infectious agents. These events are capable of clearing most bacteria, but must eventually be shut down before extended exposure to these toxic immune mediators can damage host tissues; this is often mediated through production of anti-inflammatory mediators, of which IL-10 is one of the best-described. In these studies, both $\mathrm{Bb}$-stimulated $\mathrm{M} \varnothing \mathrm{s}$ and $\mathrm{DCs}$ secrete prototypic proinflammatory cytokines, such as TNFa, IL-6, and IL-12, within $6 \mathrm{~h}$ of exposure. However, the levels appear to be substantially suppressed by Bb-elicited IL-10, since the levels of proinflammatory cytokines were significantly higher from $\mathrm{M} \varnothing \mathrm{s}$ and DCs from IL-10-1- mice or those where IL-10 was blocked by incubation with IL-10-specific antibodies. Similarly, a number of chemokines known to recruit leukocytes to infection sites were upregulated by $M \varnothing$ s and $D C$ s during $B b$ infection [76], but many of these were suppressed in the presence of Bb-elicited IL-10, particularly the neutrophilrecruiting chemokines such as KC (CXCL1) and MIP-2 $\alpha$ (CXCL2). While most of the sequella associated with Lyme disease are believed due to inflammatory responses against $\mathrm{Bb}$ or their associated agonists (e.g. lipoproteins, glycolipids, etc.) $[18,21,23,77-82]$, there have been several reports of dysregulated immune responses during the early development of Lyme disease. Notably, neutrophils are observed to migrate into skin tissues containing $\mathrm{Bb}$ within hours of infection, but these numbers are not maintained and few neutrophils are observed within 1-3 days of infection $[50,83]$, even though $\mathrm{Bb}$ numbers remain high in those tissues. The detrimental nature of this defect was noted by engineering $\mathrm{Bb}$ that constitutively produce the chemokine $\mathrm{KC}$, and infections with this strain subsequently produce a more sustained recruitment of neutrophils to the infection site, resulting in enhanced $\mathrm{Bb}$ clearance [50]. The kinetics of the abbreviated neutrophil recruitment corresponds with the significant IL-10 production seen in skin tissues by $24 \mathrm{~h}$ post-infection [42], and our findings demonstrating subsequent decreases in proinflammatory cytokines and neutrophil-attracting chemokines when IL-10 is blocked. Thus, Bb-elicited IL-10 may play a major role in the dysregulated inflammatory response observed early in the development in Lyme disease and may increase the chances of $\mathrm{Bb}$ to evade clearance by the cellular responses and subsequent dissemination to distant tissues.

In addition to phagocytosing pathogens and mediating inflammatory responses, skin-resident APCs play a major role in bridging the innate and adaptive immune responses by the presentation of antigens on MHC class II molecules to T cells, as well as surface expression of co-stimulatory molecules whose ligation is required to allow optimal activation of $\mathrm{T}$ cells, such as CD40 and the B7 family molecules CD80 and CD86 [84-86]. In our studies, co-culture of $\mathrm{M} \varnothing \mathrm{s}$ with $\mathrm{Bb}$ resulted in no upregulation of $\mathrm{MHC} \mathrm{II}$ or any of the co-stimulatory molecules assessed, but blocking Bb-elicited IL-10 did allow subsequent upregulation of MHC II and CD86. When assessing DCs, coculture with $\mathrm{Bb}$ had little effect other than an increase in the percentage of cells expressing CD86. However, removal of IL-10 allowed significant upregulation of all co-stimulatory molecules assessed. One of the hallmarks of Lyme disease is that, while infected animals eventually generate a robust and diverse antibody response, the development of this response appears to be delayed [7]. While these well-developed antibodies can prevent infection of naïve mice if administered co-currently with $\mathrm{Bb}$, they cannot confer protection if the infection has been established for even a few days $[6,87]$, suggesting that even briefly delayed development of the antibody response can promote establishment of $\mathrm{Bb}$ infection. Others have also shown that upregulation of co-stimulatory molecules by APCs in response to $\mathrm{Bb}$ is inadequate [81], and that the involvement of certain of these molecules (e.g. CD86) are needed for an optimal antibody response to $\mathrm{Bb}$ [88]. Together, these experiments suggest that the suppression of these co-stimulatory molecules on APCs by Bb-elicited IL-10 may contribute to the dysregulated adaptive responses generated during the development of Lyme disease.

Collectively, our findings indicate that both $M \varnothing s$ and DCs are rapid and potent producers of $\mathrm{IL}-10$ in response to $\mathrm{Bb}$ exposure. The IL-10 levels appear able to block many of the immune functions of these APCs that should be critical for controlling $\mathrm{Bb}$ infection, including phagocytosis/trafficking, induction of ROS and NO, secretion of inflammatory cytokines/ chemokines, and upregulation of surface co-stimulatory molecules required for optimal activation of Bb-specific adaptive responses. Because $\mathrm{M} \varnothing \mathrm{s}$ and $\mathrm{DCs}$ are believed to be largely responsible for moderating the early immune responses against $\mathrm{Bb}$ deposited into the skin, these findings suggest this IL-10 elicitation may be largely responsible for the dysregulated early leukocyte responses and delayed adaptive responses that are believed to have a major influence in the ability of $\mathrm{Bb}$ to efficiently disseminate and persist within susceptible hosts, as already suggested by the significantly enhanced $\mathrm{Bb}$ clearance and $\mathrm{Bb}$-specific antibody responses displayed by IL-10-/ mice $[37,41]$. Further studies are needed to determine whether treatments aimed at blocking these IL-10 effects can promote efficient clearance of these bacteria in both acute and chronic cases of Lyme disease.

\section{Acknowledgements}

We would like to thank Dr. Brian Stevenson (University of Kentucky) for providing the eGFP-expressing B. burgdorferi. We also thank Kari Neifer-Sadhwani for technical support.

\section{Author Contributions}

Conceived and designed the experiments: YC NZ RMW. Performed the experiments: YC NZ. Analyzed the data: YC NZ 
RMW. Contributed reagents/materials/analysis tools: RMW. Wrote the manuscript: YC NZ RMW.

\section{References}

1. Wooten RM, Weis JJ (2001) Host-pathogen interactions promoting inflammatory Lyme arthritis: use of mouse models for dissection of disease processes. Curr Opin Microbiol 4: 274-279. doi:10.1016/ S1369-5274(00)00202-2. PubMed: 11378478.

2. Radolf JD, Caimano MJ, Stevenson B, Hu LT (2012) Of ticks, mice and men: understanding the dual-host lifestyle of Lyme disease spirochaetes. Nat Rev Microbiol 10: 87-99. PubMed: 22230951.

3. Benach JL, Habicht GS, Gocinski BL, Coleman JL (1984) Phagocytic cell responses to in vivo and in vitro exposure to the Lyme disease spirochete. Yale J Biol Med 57: 599-605. PubMed: 6393611.

4. Montgomery RR, Nathanson MH, Malawista SE (1994) Fc- and non-Fcmediated phagocytosis of Borrelia burgdorferi by macrophages. J Infect Dis 170: 890-893. doi:10.1093/infdis/170.4.890. PubMed: 7930732.

5. Montgomery RR, Lusitani D, Chevance Ad Ade B, Malawista SE (2002) Human phagocytic cells in the early innate immune response to Borrelia burgdorferi. J Infect Dis 185: 1773-1779. doi:10.1086/340826. PubMed: 12085324

6. Barthold SW, Bockenstedt LK (1993) Passive immunizing activity of sera from mice infected with Borrelia burgdorferi. Infect Immun 61: 4696-4702. PubMed: 8406868

7. Hastey CJ, Elsner RA, Barthold SW, Baumgarth N (2012) Delays and Diversions Mark the Development of B Cell Responses to Borrelia burgdorferi. Infection - J Immunol.

8. Weis JJ (2002) Host-pathogen interactions and the pathogenesis of murine Lyme disease. Curr Opin Rheumatol 14: 399-403. doi: 10.1097/00002281-200207000-00011. PubMed: 12118174

9. Fraser CM, Casjens S, Huang WM, Sutton GG, Clayton R et al. (1997) Genomic sequence of a Lyme disease spirochaete, Borrelia burgdorferi. Nature 390: 580-586. doi:10.1038/37551. PubMed: 9403685.

10. Casjens S, Palmer N, van Vugt R, Huang WM, Stevenson B et al. (2000) A bacterial genome in flux: the twelve linear and nine circular extrachromosomal DNAs in an infectious isolate of the Lyme disease spirochete Borrelia burgdorferi. Mol Microbiol 35: 490-516. PubMed: 10672174.

11. Casjens SR, Mongodin EF, Qiu WG, Luft BJ, Schutzer SE et al. (2012) Genome stability of Lyme disease spirochetes: comparative genomics of Borrelia burgdorferi plasmids. PLOS ONE 7: e33280. doi:10.1371/ journal.pone.0033280. PubMed: 22432010

12. Setubal JC, Reis M, Matsunaga J, Haake DA (2006) Lipoprotein computational prediction in spirochaetal genomes. Microbiology 152 : 113-121. doi:10.1099/mic.0.28317-0. PubMed: 16385121.

13. Samuels DS (2011) Gene regulation in Borrelia burgdorferi. Annu Rev Microbiol 65: 479-499. doi:10.1146/annurev.micro.112408.134040. PubMed: 21801026.

14. Schulze RJ, Zückert WR (2006) Borrelia burgdorferi lipoproteins are secreted to the outer surface by default. Mol Microbiol 59: 1473-1484 doi:10.1111/j.1365-2958.2006.05039.x. PubMed: 16468989.

15. Kenedy MR, Lenhart TR, Akins DR (2012) The role of Borrelia burgdorferi outer surface proteins. FEMS Immunol Med Microbiol 66 : 1-19. doi:10.1111/j.1574-695X.2012.00980.x. PubMed: 22540535.

16. Wooten RM, Morrison TB, Weis $\mathrm{JH}$, Wright SD, Thieringer $\mathrm{R}$ et al. (1998) The role of CD14 in signaling mediated by outer membrane lipoproteins of Borrelia burgdorferi. J Immunol 160: 5485-5492. PubMed: 9605151

17. Sellati TJ, Bouis DA, Kitchens RL, Darveau RP, Pugin J et al. (1998) Treponema pallidum and Borrelia burgdorferi lipoproteins and synthetic lipopeptides activate monocytic cells via a CD14-dependent pathway distinct from that used by lipopolysaccharide. J Immunol 160: 5455-5464. PubMed: 9605148

18. Hirschfeld M, Kirschning CJ, Schwandner R, Wesche H, Weis JH et al. (1999) Cutting edge: inflammatory signaling by Borrelia burgdorferi lipoproteins is mediated by toll-like receptor 2. J Immunol 163: 2382-2386. PubMed: 10452971.

19. Bolz DD, Sundsbak RS, Ma Y, Akira S, Kirschning CJ et al. (2004) MyD88 plays a unique role in host defense but not arthritis development in Lyme disease. J Immunol 173: 2003-2010. PubMed: 15265935

20. Lien E, Sellati TJ, Yoshimura A, Flo TH, Rawadi G et al. (1999) Toll-like receptor 2 functions as a pattern recognition receptor for diverse bacterial products. J Biol Chem 274: 33419-33425. doi:10.1074/jbc. 274.47.33419. PubMed: 10559223.
21. Wooten RM, Ma Y, Yoder RA, Brown JP, Weis JH et al. (2002) Toll-like receptor 2 is required for innate, but not acquired, host defense to Borrelia burgdorferi. J Immunol 168: 348-355. PubMed: 11751980.

22. Liu N, Montgomery RR, Barthold SW, Bockenstedt LK (2004) Myeloid differentiation antigen 88 deficiency impairs pathogen clearance but does not alter inflammation in Borrelia burgdorferi-infected mice. Infect Immun 72: 3195-3203. doi:10.1128/IAI.72.6.3195-3203.2004. PubMed: 15155621

23. Salazar JC, Pope CD, Moore MW, Pope J, Kiely TG et al. (2005) Lipoprotein-dependent and -independent immune responses to spirochetal infection. Clin Diagn Lab Immunol 12: 949-958. PubMed: 16085913

24. Thoma-Uszynski S, Kiertscher SM, Ochoa MT, Bouis DA, Norgard MV et al. (2000) Activation of toll-like receptor 2 on human dendritic cells triggers induction of IL-12, but not IL-10. J Immunol 165: 3804-3810. PubMed: 11034386.

25. Morrison TB, Weis JH, Weis JJ (1997) Borrelia burgdorferi outer surface protein $A(O s p A)$ activates and primes human neutrophils. J Immunol 158: 4838-4845. PubMed: 9144499.

26. Marietta EV, Weis JJ, Weis JH (1997) CD28 expression by mouse mast cells is modulated by lipopolysaccharide and outer surface protein A lipoprotein from Borrelia burgdorferi. J Immunol 159: 2840-2848. PubMed: 9300707

27. Ma Y, Weis JJ (1993) Borrelia burgdorferi outer surface lipoproteins OspA and OspB possess B-cell mitogenic and cytokine-stimulatory properties. Infect Immun 61: 3843-3853. PubMed: 8359905.

28. Wooten RM, Modur VR, McIntyre TM, Weis JJ (1996) Borrelia burgdorferi outer membrane protein $\mathrm{A}$ induces nuclear translocation of nuclear factor-KB and inflammatory activation in human endothelial cells. J Immunol 157: 4584-4590. PubMed: 8906837.

29. Ebnet K, Brown KD, Siebenlist UK, Simon MM, Shaw S (1997) Borrelia burgdorferi activates nuclear factor-kappa B and is a potent inducer of chemokine and adhesion molecule gene expression in endothelial cells and fibroblasts. J Immunol 158: 3285-3292. PubMed: 9120285.

30. Yoder A, Wang X, Ma Y, Philipp MT, Heilbrun M et al. (2003) Tripalmitoyl-S-glyceryl-cysteine-dependent OspA vaccination of toll-like receptor 2-deficient mice results in effective protection from Borrelia burgdorferi challenge. Infect Immun 71: 3894-3900. doi:10.1128/IAI. 71.7.3894-3900.2003. PubMed: 12819074.

31. Iliopoulou BP, Huber BT (2010) Infectious arthritis and immune dysregulation: lessons from Lyme disease. Curr Opin Rheumatol 22: 451-455. doi:10.1097/BOR.0b013e328338f73f. PubMed: 20375899.

32. Mosser DM, Zhang $X$ (2008) Interleukin-10: new perspectives on an old cytokine. Immunol Rev 226: 205-218. doi:10.1111/j.1600-065X. 2008.00706.x. PubMed: 19161426.

33. Sabat R, Grütz G, Warszawska K, Kirsch S, Witte E et al. (2010) Biology of interleukin-10. Cytokine Growth Factor Rev 21: 331-344. doi: 10.1016/j.cytogfr.2010.09.002. PubMed: 21115385.

34. Ouyang W, Rutz S, Crellin NK, Valdez PA, Hymowitz SG (2011) Regulation and functions of the IL-10 family of cytokines in inflammation and disease. Annu Rev Immunol 29: 71-109. doi:10.1146/ annurev-immunol-031210-101312. PubMed: 21166540.

35. Giambartolomei GH, Dennis VA, Philipp MT (1998) Borrelia burgdorferi stimulates the production of interleukin-10 in peripheral blood mononuclear cells from uninfected humans and rhesus monkeys. Infect Immun 66: 2691-2697. PubMed: 9596735.

36. Giambartolomei GH, Dennis VA, Lasater BL, Philipp MT (1999) Induction of pro- and anti-inflammatory cytokines by Borrelia burgdorferi lipoproteins in monocytes is mediated by CD14. Infect Immun 67: 140-147. PubMed: 9864208.

37. Brown JP, Zachary JF, Teuscher C, Weis JJ, Wooten RM (1999) Dual role of interleukin-10 in murine Lyme disease: Regulation of arthritis severity and host defense. Infect Immun 67: 5142-5150. PubMed: 10496888.

38. Gautam A, Dixit S, Embers M, Gautam R, Philipp MT et al. (2012) Different patterns of expression and of IL-10 modulation of inflammatory mediators from macrophages of Lyme disease-resistant and -susceptible mice. PLOS ONE 7: e43860. doi:10.1371/ journal.pone.0043860. PubMed: 23024745.

39. Crandall H, Dunn DM, Ma Y, Wooten RM, Zachary JF et al. (2006) Gene expression profiling reveals unique pathways associated with 
differential severity of Lyme arthritis. J Immunol 177: 7930-7942. PubMed: 17114465.

40. Sonderegger FL, Ma Y, Maylor-Hagan H, Brewster J, Huang $X$ et al. (2012) Localized production of IL-10 suppresses early inflammatory cell infiltration and subsequent development of IFNy-mediated Lyme arthritis. J Immunol 188: 1381-1393. doi:10.4049/jimmunol.1102359. PubMed: 22180617.

41. Lazarus JJ, Meadows MJ, Lintner RE, Wooten RM (2006) IL-10 deficiency promotes increased Borrelia burgdorferi clearance predominantly through enhanced innate immune responses. J Immunol 177: 7076-7085. PubMed: 17082624.

42. Lazarus JJ, Kay MA, McCarter AL, Wooten RM (2008) Viable Borrelia burgdorferi enhances interleukin-10 production and suppresses activation of murine macrophages. Infect Immun 76: 1153-1162. doi: 10.1128/IAI.01404-07. PubMed: 18086805.

43. Nestle FO; Di Meglio P, Qin JZ, Nickoloff BJ (2009) Skin immune sentinels in health and disease. Nat Rev Immunol 9: 679-691. PubMed: 19763149. Available online at: PubMed: 19763149

44. Weis JJ, Bockenstedt LK, editors (2010) Borrelia: Molecular Biology, Host Interaction, and Pathogenesis. Norfolk, UK: Caister Academic Press. pp. 413-441.

45. Barthold SW, Beck DS, Hansen GM, Terwilliger GA, Moody KD (1990) Lyme borreliosis in selected strains and ages of laboratory mice. J Infect Dis 162: 133-138. doi:10.1093/infdis/162.1.133. PubMed: 2141344.

46. Barbour AG (1984) Isolation and cultivation of Lyme disease spirochetes. Yale J Biol Med 57: 521-525. PubMed: 6393604

47. Miller JC, von Lackum K, Woodman ME, Stevenson B (2006) Detection of Borrelia burgdorferi gene expression during mammalian infection using transcriptional fusions that produce green fluorescent protein. Microb Pathog 41: 43-47. doi:10.1016/j.micpath.2006.04.004. PubMed: 16723206.

48. Matsushima H, Tanaka H, Mizumoto N, Takashima A (2009) Identification of crassin acetate as a new immunosuppressant triggering heme oxygenase-1 expression in dendritic cells. Blood 114: 64-73. doi:10.1182/blood-2009-02-204297. PubMed: 19401559.

49. Ding AH, Nathan CF, Stuehr DJ (1988) Release of reactive nitrogen intermediates and reactive oxygen intermediates from mouse peritoneal macrophages. Comparison of activating cytokines and evidence for independent production. J Immunol 141: 2407-2412. PubMed: 3139757.

50. Xu Q, Seemanapalli SV, Reif KE, Brown CR, Liang FT (2007) Increasing the recruitment of neutrophils to the site of infection dramatically attenuates Borrelia burgdorferi infectivity. J Immunol 178: 5109-5115. PubMed: 17404293.

51. Montgomery RR, Lusitani D, De Boisfleury Chevance A, Malawista SE (2004) Tick saliva reduces adherence and area of human neutrophils. Infect Immun 72: 2989-2994. doi:10.1128/IAI.72.5.2989-2994.2004. PubMed: 15102811.

52. Cinco M, Murgia R, Perticarari S, Presani G (1994) Simultaneous measurement by flow cytometry of phagocytosis and metabolic burst induced in phagocytic cells in whole blood by Borrelia burgdorferi. FEMS Microbiol Lett 122: 187-193. doi:10.1111/j. 1574-6968.1994.tb07163.x. PubMed: 7958771

53. Marangoni A, Accardo S, Aldini R, Guardigli M, Cavrini F et al. (2006) Production of reactive oxygen species and expression of inducible nitric oxide synthase in rat isolated Kupffer cells stimulated by Leptospira interrogans and Borrelia burgdorferi. World J Gastroenterol 12: 3077-3081. PubMed: 16718791.

54. Giambartolomei GH, Dennis VA, Lasater BL, Murthy PK, Philipp MT (2002) Autocrine and exocrine regulation of interleukin-10 production in THP-1 cells stimulated with Borrelia burgdorferi lipoproteins. Infect Immun 70: 1881-1888. doi:10.1128/IAI.70.4.1881-1888.2002. PubMed: 11895951.

55. Gautam A, Dixit S, Philipp MT, Singh SR, Morici LA et al. (2011) Interleukin-10 alters effector functions of multiple genes induced by Borrelia burgdorferi in macrophages to regulate Lyme disease inflammation. Infect Immun 79: 4876-4892. doi:10.1128/IAI.05451-11. PubMed: 21947773

56. Shin OS, Isberg RR, Akira S, Uematsu S, Behera AK et al. (2008) Distinct roles for MyD88 and Toll-like receptors 2, 5, and 9 in phagocytosis of Borrelia burgdorferi and cytokine induction. Infect Immun 76: 2341-2351. doi:10.1128/IAI.01600-07. PubMed: 18378636.

57. Salazar JC, Duhnam-Ems S, La Vake C, Cruz AR, Moore MW et al. (2009) Activation of human monocytes by live Borrelia burgdorferi generates TLR2-dependent and -independent responses which include induction of IFN $\beta$. PLOS Pathog 5: e1000444.
58. Montgomery RR, Malawista SE (1996) Entry of Borrelia burgdorferi into macrophages is end-on and leads to degradation in lysosomes. Infect Immun 64: 2867-2872. PubMed: 8698527.

59. Nathan CF, Hibbs JB Jr. (1991) Role of nitric oxide synthesis in macrophage antimicrobial activity. Curr Opin Immunol 3: 65-70. doi: 10.1016/0952-7915(91)90079-G. PubMed: 1711326.

60. Dale DC, Boxer L, Liles WC (2008) The phagocytes: neutrophils and monocytes. Blood 112: 935-945. doi:10.1182/blood-2007-12-077917. PubMed: 18684880

61. Flannagan RS, Cosío G, Grinstein S (2009) Antimicrobial mechanisms of phagocytes and bacterial evasion strategies. Nat Rev Microbiol 7: 355-366. doi:10.1038/nrmicro2128. PubMed: 19369951.

62. Moreira AP, Dias-Melicio LA, Soares AM (2010) Interleukin-10 but not Transforming Growth Factor beta inhibits murine activated macrophages Paracoccidioides brasiliensis killing: effect on $\mathrm{H} 2 \mathrm{O} 2$ and NO production. Cell Immunol 263: 196-203. doi:10.1016/j.cellimm. 2010.03.016. PubMed: 20417928

63. Boylan JA, Gherardini FC (2008) Determining the cellular targets of reactive oxygen species in Borrelia burgdorferi. Methods Mol Biol 431: 213-221. PubMed: 18287759.

64. Boylan JA, Lawrence KA, Downey JS, Gherardini FC (2008) Borrelia burgdorferi membranes are the primary targets of reactive oxygen species. Mol Microbiol 68: 786-799. doi:10.1111/j. 1365-2958.2008.06204.x. PubMed: 18373524.

65. Seiler KP, Vavrin Z, Eichwald E, Hibbs JB Jr., Weis JJ (1995) Nitric oxide production during murine Lyme disease: lack of involvement in host resistance or pathology. Infect Immun 63: 3886-3895. PubMed: 7558296.

66. Ma Y, Seiler KP, Tai KF, Yang L, Woods M et al. (1994) Outer surface lipoproteins of Borrelia burgdorferi stimulate nitric oxide production by the cytokine-inducible pathway. Infect Immun 62: 3663-3671. PubMed: 7520417.

67. Shortman K, Naik SH (2007) Steady-state and inflammatory dendriticcell development. Nat Rev Immunol 7: 19-30. doi:10.1038/nri1996. PubMed: 17170756.

68. Serbina NV, Salazar-Mather TP, Biron CA, Kuziel WA, Pamer EG (2003) TNF/iNOS-producing dendritic cells mediate innate immune defense against bacterial infection. Immunity 19: 59-70. doi:10.1016/ S1074-7613(03)00171-7. PubMed: 12871639

69. Geissmann F, Manz MG, Jung S, Sieweke MH, Merad M et al. (2010) Development of monocytes, macrophages, and dendritic cells. Science 327: 656-661. doi:10.1126/science.1178331. PubMed: 20133564.

70. Cortez-Retamozo V, Etzrodt M, Pittet MJ (2012) Regulation of macrophage and dendritic cell responses by their lineage precursors. $J$ Innate Immun 4: 411-423. doi:10.1159/000335733. PubMed: 22433183.

71. Crandall H, Ma Y, Dunn DM, Sundsbak RS, Zachary JF et al. (2005) $\mathrm{Bb} 2 \mathrm{Bb} 3$ regulation of murine Lyme arthritis is distinct from Ncf1 and independent of the phagocyte nicotinamide adenine dinucleotide phosphate oxidase. Am J Pathol 167: 775-785. doi:10.1016/ S0002-9440(10)62050-0. PubMed: 16127156.

72. Brown CR, Reiner SL (1999) Development of lyme arthritis in mice deficient in inducible nitric oxide synthase. J Infect Dis 179: 1573-1576. doi:10.1086/314774. PubMed: 10228086.

73. Bourret TJ, Boylan JA, Lawrence KA, Gherardini FC (2011) Nitrosative damage to free and zinc-bound cysteine thiols underlies nitric oxide toxicity in wild-type Borrelia burgdorferi. Mol Microbiol 81: 259-273. doi: 10.1111/j.1365-2958.2011.07691.x. PubMed: 21564333.

74. Esteve-Gassent MD, Elliott NL, Seshu J (2009) sodA is essential for virulence of Borrelia burgdorferi in the murine model of Lyme disease. Mol Microbiol 71: 594-612. doi:10.1111/j.1365-2958.2008.06549.x. PubMed: 19040638.

75. Posey JE, Gherardini FC (2000) Lack of a role for iron in the Lyme disease pathogen. Science 288: 1651-1653. doi:10.1126/science. 288.5471.1651. PubMed: 10834845.

76. Behera AK, Hildebrand E, Bronson RT, Perides G, Uematsu S et al. (2006) MyD88 deficiency results in tissue-specific changes in cytokine induction and inflammation in interleukin-18-independent mice infected with Borrelia burgdorferi. Infect Immun 74: 1462-1470. doi:10.1128/IAI. 74.3.1462-1470.2006. PubMed: 16495516.

77. Kinjo Y, Tupin E, Wu D, Fujio M, Garcia-Navarro R et al. (2006) Natural killer $T$ cells recognize diacylglycerol antigens from pathogenic bacteria. Nat Immunol 7: 978-986. doi:10.1038/ni1380. PubMed: 16921381.

78. Berende A, Oosting M, Kullberg BJ, Netea MG, Joosten LA (2010) Activation of innate host defense mechanisms by Borrelia. Eur Cytokine Netw 21: 7-18. PubMed: 20146985. 
79. Singh SK, Girschick HJ (2006) Toll-like receptors in Borrelia burgdorferi-induced inflammation. Clin Microbiol Infect 12: 705-717. PubMed: 16842565.

80. Bouis DA, Popova TG, Takashima A, Norgard MV (2001) Dendritic cells phagocytose and are activated by Treponema pallidum. Infect Immun 69: 518-528. doi:10.1128/IAI.69.1.518-528.2001. PubMed: 11119545.

81. Suhonen J, Komi J, Soukka J, Lassila O, Viljanen MK (2003) Interaction between Borrelia burgdorferi and immature human dendritic cells. Scand J Immunol 58: 67-75. doi:10.1046/j. 1365-3083.2003.01284.x. PubMed: 12828560.

82. Miller JC, Ma Y, Bian J, Sheehan KC, Zachary JF et al. (2008) A critical role for type I IFN in arthritis development following Borrelia burgdorferi infection of mice. J Immunol 181: 8492-8503. PubMed: 19050267.

83. Barthold SW (1996) Lyme borreliosis in the laboratory mouse. Journal Spirochetal and Tick-Borne Diseases 3: 22-44.
84. Steinman RM, Idoyaga J (2010) Features of the dendritic cell lineage. Immunol Rev 234: 5-17. doi:10.1111/j.0105-2896.2009.00888.x. PubMed: 20193008

85. Liu K, Nussenzweig MC (2010) Origin and development of dendritic cells. Immunol Rev 234: 45-54. doi:10.1111/j.0105-2896.2009.00879.x. PubMed: 20193011

86. Hume DA (2008) Macrophages as APC and the dendritic cell myth. J Immunol 181: 5829-5835. PubMed: 18941170.

87. Barthold SW, deSouza M, Feng S (1996) Serum-mediated resolution of Lyme arthritis in mice. Lab Invest 74: 57-67. PubMed: 8569198.

88. Shanafelt MC, Kang I, Barthold SW, Bockenstedt LK (1998) Modulation of murine Lyme borreliosis by interruption of the B7/CD28 T-cell costimulatory pathway. Infect Immun 66: 266-271. PubMed: 9423867. 